\title{
THE RELATIONSHIP BETWEEN WORK-FAMILY CONFLICT AND CENTRAL LIFE INTERESTS AMONGST SINGLE WORKING MOTHERS
}

\author{
TARYN WALLIS \\ LINDA PRICE \\ Section of Organisational Psychology \& Human Resource Management \\ School of Management Studies \\ University of Cape Town
}

\begin{abstract}
This study explored the experiences of work-family conflict amongst a group of twenty single working mothers with pre-school age children. Dubin's (1992) theory of Central Life Interests was utilised to fully understand how the differential importance of the roles played by the women informed the level and nature of the conflict experienced. A two-phase research design was employed in which questionnaire responses from the first phase formed the basis for the second phase of in-depth qualitative interviews. Results indicated that participants viewed motherhood as their Central Life Interest and that this priority could lead them to experience greater conflict between work and family demands. Although work was rated second in importance when compared to family, it was still seen as being of great significance, not only for instrumental reasons, but also for the intellectual stimulation that it provided and opportunities to exercise independence and responsibility.
\end{abstract}

\section{OPSOMMING}

Die werk-en-familie konflik-ervarings van twintig werkende enkel-moeders met voorskoolse kinders is ondersoek in hierdie projek. Dubin (1992) se teorie van sentrale lewensbelangstellings is gebruik om te bepaal hoe die belangrikheid van die twee rolle die vlak en aard van die konflik bepaal het. Die navorsing is in twee fases gedoen: ' $n$ vraelys in die eerste fase, opgevolg deur in-diepte kwalitatiewe onderhoude. Resultate het gewys dat die deelnemers moederskap as hul sentrale lewensbelangstelling beskou het, en dat hierdie prioriteit kon lei tot groter konflik tussen die eise van werk en familie. Alhoewel werk as ondergeskik aan familie beoordeel is, was dit nogtans van groot belang. Aan die een kant was dit vir instrumentele redes, maar dit het ook intellektuele stimulasie verskaf en geleenthede gegee om onafhanklik en verantwoordelik op te tree.

The last decade has witnessed a sharp increase in the employment of women in the South African workforce (Census96, 1996). This trend is reflected globally and it is estimated that about two-thirds of new entrants to the labour force since the 1970s are single and married mothers (Anderson, 1997; Nickols, 1994). This scenario has implications for business in that issues that pertain to women's experiences in an employment context need to be addressed (Erasmus, 1997).

The traditional western family structure, in which the husband is the breadwinner and the wife the homemaker, has largely fallen away (Nickols, 1994). The dual-worker family has become accepted as the new norm. However, households headed by single mothers are also very prevalent today. Gringlas and Weinraub (1995) report an increase of $300 \%$ in the number of single parent family units in America over the last two decades, $90 \%$ of which are single working mothers (Silva, 1996). Global statistics state that a quarter of all families with dependent children are headed by single mothers (Burns \& Scott, 1994) and South African statistics reveal the existence of nearly 3.5 million female heads of households (Census96, 1996).

Nickols (1994) describes this situation as a tipping point whereby old social norms have declined in importance but have not yet been replaced by new social norms to create alternative patterns of family and work life. This is evident in the limited studies that explore the experiences of single working mothers, who are usually included in the general category of employed mothers. Issues that are unique to their experience are thus overlooked (Duxbury, Higgins \& Lee, 1994).

As a result, support systems and work schedules have not been sufficiently adjusted to allow for the integration of work and family roles (Nickols, 1994). Patterns of employment, housing and childcare assume a dual-parent family, and non-statutory discrimination against single mothers is still an issue in many

Requests for copies should be addressed to: $T$ Wallis, School of Management

Studies, University Cape Town, Private Bag, Rondebosch, 7700 countries (Burns \& Scott, 1994). This discrimination arises out of the perception that single mothers impose high costs on society through increased welfare costs and negative developmental effects on children (Burns \& Scott; Millar, 1996).

These negative perceptions of single motherhood are often emphasised in the research due to the adoption of comparative approaches that examine how 'atypical' single-parent families differ from 'normal' dual-parent households, thus increasing the marginalisation of single mothers (Smith, 1997). The negative consequences of single motherhood that have been identified reveal that single mothers have poorer quality housing, limited earning capacity, and less time available for themselves (Burns \& Scott, 1994; Simons \& Conger, 1993; Smith). These findings are particularly relevant to single working mothers who are employed in unskilled, low-income occupations.

However, Gringlas and Weinraub (1995) conducted a comparative study of the experiences of professional single and married mothers. They concluded that, although the single working mothers experienced higher levels of stress, the two groups were indistinguishable in terms of effective parenting practices, including psychological control, maternal nurturance and communication skills. Levels of stress were related to the strain of working a double day, facing the challenges of childcare and household responsibilities in addition to problems in the workplace (Gringlas \& Weinraub; Erasmus, 1997). This has been dubbed a 'second shift' by Hochschild (1990). Despite these stressors, single working mothers have reported feelings of confidence, pride, decisiveness, achievement and independence (Smith, 1997). Interestingly, the characteristics of autonomy and self-sufficiency that single mothers use to describe themselves are traditionally relegated by society to the male role (Smart, 1999).

As work and family roles have frequently been studied as components of a work-life role system (Pleck, 1985), this study chose to examine work-family conflict in conjunction with Dubin's (1992) theory of Central Life Interests (CLI). 
According to Dubin (1956, cited in Baba, 1989), a CLI is an individual's expressed preference for carrying out an activity in a particular domain. The individual attaches emotional significance to the situation as it embodies "that portion of a person's total life in which energies are invested in both physical/intellectual activities and in positive emotional states" (Dubin, 1992, pp. $40-41$ ). This is similar to the concept of psychological centrality that is described by Rosenberg and Pearlin (1978, cited in Gecas \& Seff, 1990) as the circumstances where some elements of the individual's self-concept occupy the centre of attention, while others remain peripheral concerns. The impact of any element on self-esteem is thus dependent on its degree of importance within the individual's cognitive structure.

Research on work-family conflict recognises the interdependence between work and family domains and examines how the simultaneous performance of interdependent roles of employee, parent and spouse, with their related demands in terms of time, energy and commitment, can cause the individual to experience role conflict (Eagle, Icenogle, Maes \& Miles, 1998; Voydanoff, 1993). Role conflict arises when the fulfilment of one role is hindered by participation in another role (Voydanoff, 1993).

As a form of inter-role conflict, work-family conflict takes two forms. Role overload occurs when cumulative demands on the individual's time and energy exceed the individual's ability to perform either role competently, and role interference exists when the demands from two or more roles conflict to the extent that the requirements of neither can be accomplished (Duxbury \& Higgins, 1991; Voydanoff, 1993). Role interference in workfamily conflict is recognised as bi-directional, in that role strain can arise out of interference from family to work as well as out of interference from work to family (Duxbury et al., 1994; Eagle et al., 1998).

The conflict that arises from work-to-family and from familyto-work interference can take one of two forms. The first is time-based conflict, which occurs when the amount of time devoted to fulfilling obligations in one domain reduces the amount of time available to perform roles in the other domain (Netemeyer, Boles \& McMurrian, 1996; O'Driscoll, Ilgen \& Hildreth, 1992; Small \& Riley, 1990). The amount and nature of work-family conflict perceived by the individual is reported to increase in direct proportion to the number of hours spent in each role. Research has found that women experience more family-to-work interference than men as they spend more time in the family domain (Gutek, Searle \& Klepa, 1991; Duxbury et al., 1994). The total time spent in both roles is positively related to role overload (Duxbury et al.). The second form is strain-based conflict which arises when strain produced by one role, such as irritability, fatigue and anxiety, prevents role demands in the other domain from being fulfilled (Netemeyer et al., 1996).

Three different perspectives have been proposed with respect to the manner in which work and family roles interact. Firstly, segmentation theory assumes that work and family are independent domains and that individuals can separate them in terms of time, physical location, emotions, attitudes and behaviour (Lambert, 1990). Secondly, compensation theory postulates that people who are not satisfied in one domain will seek satisfaction in the other domain (Lambert). The third and most popular hypothesis is that of spillover, which theorises that attitudes and behaviours from one role accumulate and extend into other roles (Kossek \& Ozeki, 1998; Leiter \& Durup, 1996). According to Kossek and Ozeki, spillover should not be viewed as either good or bad, but researchers should be aware that individual differences, such as personal disposition, gender, family structure and family role, could have an effect on how conflict is handled.

\section{RESEARCH PURPOSE AND RESEARCH QUESTIONS}

Previous research (e.g. Eagle et al., 1998; Wiley, 1991) has found a relationship between work-family conflict and the constructs of work/family involvement, role expectations and identity theory. As these are related to the concept of Central Life Interests, it was postulated that there would also be a relationship between work-family conflict and CLIs. The purpose of the paper was therefore to examine the relevance of Dubin's (1992) theory of Central Life Interests for understanding the nature and level of work-family conflict amongst single working mothers.

In particular, the following research questions guided the study:

- Which role is accorded utmost importance in the lives of single working mothers?

- What role does work play in the lives of single working mothers?

- Does the choice of most important role have an effect on the levels of work-family conflict experienced?

- What are the levels of work-family conflict experienced by single working mothers?

- What is the nature of the work-family conflict experienced by single working mothers?

- How do single working mothers cope with the work-family conflict that they experience?

\section{METHOD}

The study followed a two-phase research design. The utilisation of the quantitative technique of a questionnaire in the first phase provided the objective identification of issues that could be explored in greater detail during the in-depth qualitative interviews that comprised the second stage.

\section{Participants}

Twenty women participated in this study, all of whom were single mothers with at least one child under the age of seven. The women worked for different branches of a large financial services institution in the Western Cape. Examining women with specific life circumstances and in a particular context provided a comprehensive understanding of the issues and challenges faced by single mothers. The decision to restrict the sample to those with pre-school age children was based on the fact that this age group requires more intensive care than older, more self-sufficient children (Goldberg, Greenberger, Hamill \& O’Neil, 1992).

\section{Measuring instruments}

The questionnaire that was used in phase one of this research was compiled by the researchers, and consisted of three sections. The first section focused on participants' biographical details, while the second section measured participants' levels of workfamily conflict via the work-family role strain instrument developed by Bohen and Viveros-Long (1981). This instrument uses a five-point Likert scale to measure three sub-scales, each of which measures one of the three forms of role strain produced by work-family conflict, namely role overload (five statements), work-to-family interference (four statements), and family-towork interference (five statements). Each sub-scale is scored separately, and the sum of these measures provides a global score for work-family conflict. The higher the score on the instrument, the higher the individual's level of work-family conflict. Duxbury et al. reported reliabilities of 0.85 for the overload scale, 0.67 for work-to-family interference, and 0.69 for familyto-work interference. In this research, the following Cronbach alphas were found: 0.88 for the overall scale, 0.93 for the role overload sub-scale, 0.60 for work-to-family interference, and 0.67 for family-to-work interference. The alphas for the subscales show the same pattern as reported by Duxbury et al. 
The third section of the questionnaire consists of an adaptation of Dubin's (1992) method to elicit respondents' Central Life Interests. Dubin's method required individuals to generate their own environmental settings, or domains, from which a CLI could be chosen. In this research, however, participants were provided with five domains - work, immediate household, extended family, social and community - as well as roles that could fit into each setting. Participants were also given the opportunity to add more roles if required. This adaptation was considered necessary in order to ensure that participants provided information on the environmental settings that were of interest to this research, as well as to increase the ease of completion of the questionnaire.

Participants were then asked to indicate which roles in each setting applied to them, and to also provide adjectives that they felt described the personality characteristics that they displayed in each role. Respondents then indicated which role they deemed most important as well as the reasons for their choice. Lastly, participants rated each environment objectively in terms of its importance to them.

Finally, participants were required to indicate the levels of conflict between each of the environments, and to answer openended questions relating to methods of coping with conflicts of interest, as well as the challenges that they faced as single working mothers. The use of open-ended questions here allowed respondents to provide more thorough information on issues dealt with in the questionnaire and to highlight areas previously not considered, but which could be included in later interview discussions (Lewis, Saunders \& Thornhill, 1997).

\section{Procedure}

Phase 1

The questionnaire was distributed in the Western Cape via the internal e-mail system of the financial services institution using employee mailing lists. A total of fourteen questionnaires were returned. Although sufficient for the purposes of this study, this does represent a low response rate. Duxbury et al. (1994) have stated that single parents with young children are less likely to be in the workforce than those with older children, and this could provide a potential explanation for the small response. Other possible reasons for this include reluctance to participate in the study because of the personal nature of the content, and the ease of forgetting about a questionnaire on e-mail, particularly if the individual has a large volume of work.

Phase 2

A purposive sampling process generated a sample of thirteen women, seven of whom had already completed questionnaires. Semi-structured interviews were conducted with each participant. Interviewees who had not completed a questionnaire were asked to provide the interviewer with biographical information and to complete the scale on workfamily conflict so as to obtain a quantitative measure of the phenomena for all participants.

\section{Data Analysis}

After completion of the two phases, the distribution of participants between questionnaires and interviews was as follows. Seven women had only completed questionnaires, seven had completed questionnaires during the quantitative phase of the research as well as responded to the request for interviews, and six women had only responded to the interview request (although they had also completed the scale on workfamily conflict during the interview). For the purposes of data analysis, therefore, biographical data obtained from the interviews was combined with that from the questionnaires, and descriptive statistics were carried out to identify the characteristics of the entire sample. Information from the work-family conflict scale completed in the interviews was also combined with that from the earlier questionnaires, and t-tests for independent samples were carried out to determine the level of work-family conflict (overall and each sub-scale) experienced by those who chose motherhood as a CLI and those who chose another role.

The technique of content analysis was utilised to examine the remaining interview data. This process resulted in the emergence of the following themes:

- Main theme: The relationship between CLI and work-family conflict

- Sub-themes:

- Participants' perceptions of their identity as single working mothers

- The role played by work in the lives of single working mothers

- Moderating effects on work-family conflict

- Coping strategies

\section{RESULTS \& DISCUSSION}

Before moving on to examine the relationship between Central Life Interests and work-family conflict, it is necessary to locate these results in context by providing findings with respect to participants' experiences of Central Life Interests and workfamily conflict.

In line with Dubin's (1992) theory, participants in this study showed very strong orientations towards one specific domain and, in turn, one particular role within that domain. Specifically, fifteen women stated unequivocally that the family setting and their role of mother within that setting was the most important to them. This Central Life Interest was chosen because they felt a sense of duty and responsibility towards their children, and also felt happy and fulfilled in their performance of the role. For example, the women made comments such as "When I'm with [my daughter] I'm the happiest person" and "My children are number one with me, they come first. I want to be a good mother to them, give them what they need". Family variables are thus seen to impact significantly on the self-esteem of the women in this study (Gecas \& Seff, 1990).

The finding that most women chose motherhood as their CLI supports Gutek et al.'s (1991) argument that, if forced to choose between the two central institutions of work and family, most people would rate family more highly than work in terms of importance. This is considered to be especially true for women, who are more likely to allocate a central role to family (Harpaz $\& \mathrm{Fu}, 1997)$. Participants' answers may also contain an element of social desirability as society expects women to allocate greater importance to the family domain than to work (Wiley, 1991). Research has reported that working women are willing to change their career and work plans to accommodate their families (Barber \& Monaghan, 1988, cited in Wiley, 1991). Female college students have also been found to allocate priority to their future family roles even if they intend to have careers as well (Barber \& Monaghan, cited in Wiley). This was supported in the current study by the finding that most of the women wished to tailor their working lives around the needs of their families, either by remaining with the organisation in a 'behind-the scenes' capacity and working flexitime, or by leaving the organisation to find a more suitable job, for example, in a day-care capacity.

Participants stated that they had developed characteristics such as strength and independence from their experience as single working mothers. They considered this to be a positive aspect of being a single working mother and expressed a feeling of accomplishment. One woman stated that she was aware that her staff saw her as a role model - "They look up to me, they think I'm this superwoman. They don't realise how hard it is". Previous research has reported similar characteristics, and has commented that these attributes are usually associated 
with the male role in society (Smith, 1997). Other personality characteristics cited by the women as applying to their role as mother included being caring, honest, responsible, patient, concerned, spontaneous and understanding. Nine women reported that there was extreme consistency between their personalities at home and at work, while only two women stated that they became totally different people at work. Although Dubin's (1992) theory allows for behavioural inconsistencies between various institutions, the fact that these women are able to express positive CLI behaviours in the work domain could prove to be an advantage for the company, as these characteristics encompass both 'hard' and 'soft' features. For example, one woman stated that " $I$ ' $m$ in charge of four staff members and I must check their work. But if someone's done something wrong, I won't get angry. I help them to correct it because maybe they just forgot something. It happens". Another woman also argued that "I'm a mother, who's willing to support her son in every way, and hopefully $I$ bring that sort of thing to work where I attend to my job in the same sort of way".

Questionnaire responses indicated that, although work emerged as being of secondary importance when compared with the home environment, it was still consistently rated as being very important. The interviews therefore probed the reasons behind these responses to explore the role played by work in the lives of participants. Findings showed that, in line with other research on the experiences of women, the majority of participants expressed an instrumental orientation towards work (Wiley, 1991). They also acknowledged that work played an important role in their lives by providing stimulation, keeping loneliness at bay and allowing them to express their independence. This was expressed by the finding that, of those participants who did choose another role as their CLI, only two were work-related, and they were still given equal importance with motherhood. For example, one participant argued that, although being a mother was of great importance, she needed the additional stimulation of work. The other felt that she could not be a good mother if she did not have a job. When money was taken out of the equation, however, this woman stated that being a mother represented the most important role in her life.

The instrumental motivation to work for the participants in this study encompassed being able to fulfil family responsibilities through working to provide for the family. For example, one woman stated, "The reason why my career is important is because I'm doing it for my children as well". This finding is most often reported for men, and is based on identity theory, which postulates that the value attached by an individual to each role they play is determined by factors such as gender (Wiley, 1991). However, single mothers have to fulfil both roles in the family and hence it is not surprising that this result was reported. Unlike men, though, whose identity is also traditionally linked to their work role, the identity of the single mothers in this study was firmly entrenched in their family role. Thompson and Ensminger (1989, cited in Wiley) have argued that the work and family identities of single mothers may overlap, without a reduction in the intensity of commitment to the family role. However, an increase in stress may be related to the identity conflict experienced.

This stress from conflict between work and family was explored by means of results obtained on the role strain instrument (Bohen \& Viveros-Long, 1981). Table 1 presents the means and standard deviations for the global scale as well as each sub-scale.
TABLE 1

RESPONDENTS' LEVELS OF WORK-FAMILY CONFLICT

\begin{tabular}{lcc}
\hline & $\begin{array}{c}\text { Mean } \\
\text { (Entire sample, } \mathrm{n}=20)\end{array}$ & Standard deviation \\
\hline Work-family conflict & 44.75 & 11.97 \\
Role overload & 18.45 & 6.01 \\
Work-to-family interference & 12.70 & 3.37 \\
Family-to-work interference & 13.60 & 4.76 \\
\hline
\end{tabular}

These results indicate that the levels of work-family conflict, role overload, and the two types of interference for the entire sample can be stated to be medium to high, although there was considerable deviation. No literature was found that reported levels of work-family conflict for other samples on this instrument, so unfortunately no comparisons could be carried out to investigate whether or not these levels are in line with other research on single working mothers. Duxbury et al. (1994) used this instrument with a sample of both single and married parents. They reported that the single parents experienced slightly higher levels of work-family conflict. This finding is supported by other research using different instruments (e.g. Belle, 1990, cited in Duxbury et al.).

Despite the findings regarding levels of conflict, the women in this study perceived very little conflict of interest between the various environments in which they spent time. Areas in which conflict was perceived, albeit low, were between the work and home environments, between immediate and extended family, and between the home environment and social life. In the interviews, this anomalous finding was also evident. When asked directly whether any conflict was experienced, five women stated that they experienced no conflict between work and family, in spite of giving examples to the contrary. A possible reason for this is perhaps a perception that the conflict experienced is not out of the ordinary for single working mothers. Another possibility is that perceptions of conflict are low because the women feel that by fulfilling work responsibilities they are also fulfilling family responsibilities by providing for their families. This is a perspective traditionally associated with men (Wiley, 1991). There was thus no evidence that, at the cognitive level, participants were distressed as a result of conflict between their work and family roles (ChiChing, 1995).

Exploration of critical incidents in the interviews revealed that participants experienced both time-based and strain-based conflict. Although both family-to-work and work-to-family interference was present, family-to-work interference was found to be more prevalent. This could be a result of women being more sensitised to family-to-work interference owing to increased psychological involvement in the family domain (Gutek et al., 1991).

A t-test for independent samples was conducted on global workfamily conflict scores as well as scores for each of the three subscales to investigate whether significant differences existed between women who chose motherhood as a Central Life Interest $(n=16)$ and those who chose another role $(n=4)$. For global work-family conflict, results indicated that there was no significant difference between women with motherhood as a CLI and those whose CLI lay elsewhere $(p=0.11)$. However, a definite trend is evident that indicates that choosing motherhood as a CLI could lead to higher levels of work-family conflict. The results of the t-test for role overload revealed a significant difference between the two groups $(\mathrm{p}=0.02)$, while no significant difference was found between the groups with respect to work-to-family interference $(\mathrm{p}=0.27)$ and family-towork interference $(\mathrm{p}=0.70)$. However, these also reveal a trend that should be tested with a larger sample. 
With respect to these findings regarding the relationship between CLI and work-family conflict, the direction of the relationships requires consideration. Mannheim, Baruch and Tal (1997) have argued that work and family involvement could potentially represent outcomes instead of antecedents of workfamily conflict. For example, individuals experiencing conflict within the family as a result of work commitments may increase their level of job involvement to avoid the conflictual situation. The same could thus apply to choice of CLI. In the context of this research, this hypothesis would postulate that participants would be experiencing conflict within the work domain as a result of family commitments, and that this would lead them to withdraw more from work and focus instead on the family. However, the participants in this study described their work environments as sensitive to their family responsibilities. This hypothesis may therefore not apply in this situation. Although the environment was sensitive, the women tended to keep their family problems to themselves. The reason for this could be that they feel that it is inappropriate to bring these issues into the workplace. Also, many participants mentioned that they come from a close family, and thus may be more inclined to seek support there rather than burden work colleagues.

Overall, the level of support expressed by participants was high, with participants receiving support from family members, partners and work colleagues. The predominant form of support was emotional, although family members also provided financial support and assistance with childcare. In line with other research (Parish \& Hao, 1991), respondents seemed reluctant to ask family to provide all-day childcare, instead relying on either solely non-family childcare or a mixture of the two. This could either result from participants' own feelings of not wanting to burden their family, or from family not being willing to undertake full responsibility for childcare. The level and types of support experienced by participants has been shown by research to reduce workfamily conflict levels, especially strain-based and time-based family-to-work interference (Eagle et al., 1998). For single mothers, in particular, a supportive social environment has been found to impact positively on their well-being (Goldberg et al., 1992).

Few studies have examined women's subjective perceptions regarding their success in balancing work and family (Milkie \& Peltola, 1999). Questionnaire responses in this research indicated that, for the most part, the women felt successful in coping with the challenges that they faced. The perception of coping successfully was confirmed by eight of the women, while the others felt ambivalent about their coping skills. One woman, who felt that she coped successfully, argued that this perception had a great deal to do with motherhood - "If you accomplish giving birth to a child, and you accomplish raising him to six and a half then you can accomplish anything you want to, for the rest of your life". Milkie and Peltola (1999) argued that women tend to arrive at their perceptions of success in coping based on comparisons with other similarly strained women that they know. The underlying reasons for feelings of success were not explored in this study, but it can be conjectured that, for some women at least, comparisons were being made with married women. The reason for making this assumption is based on the fact that some participants mentioned that they felt that they had an easier time because they did not have to also worry about taking care of a husband in conjunction with other responsibilities.

Discussions of coping strategies revealed that nine of the women in this sample attempted to reduce conflict between work and family by separating the two via segmentation, whereby each domain is kept separate in terms of time, physical location, attitudes and behaviour (Chi-Ching, 1995). One woman justified this type of coping style as follows: "I switch off completely from work, otherwise I'd end up taking the stress out on my children". In five of these cases, the women mentioned a specific activity that enabled them to switch off from work when entering the home environment, such as relaxing for half an hour, taking a bath, shopping, playing with their child, or distracting themselves with household chores.

Evidence of spillover was also apparent in the sample, however, with both positive and negative emotions from each domain extending into the other domain (Kossek \& Ozeki, 1998). This often occurred when something significant had happened. For example, one woman who was dealing with an unpleasant staff situation at work made the following comment: "Usually when I get home, I talk a lot with the children, but when I've got a lot on my mind like on Friday, then I'm very quiet. It's difficult to switch off sometimes, especially if it's a big thing".

Six women stated that when they began to feel that they could not cope emotionally with negative spillover situations, they would cry and then engage in self-talk in order to make themselves feel positive again. They stated that they could not afford to dwell on problems, but instead had to proactively solve difficulties as they arose. This was indicated by comments such as, "There's nothing I can do about it, I have to accept it and adapt to the situation. I have to make myself positive to cope - I inspire myself or I talk to others" and "I feel you can't sit around and mope, you have to make yourself feel positive."

The fact that there is evidence of both the spillover and segmentation hypotheses can be explained by the developmental perspective on work-family interfaces. This perspective takes a longitudinal and dynamic view in analysing the relationship between work and family roles during an individual's life span. It thus assumes that as the pattern of adult development differs for each individual, and as family and career demands fluctuate according to the individual's current stage of family/career development, individuals will link their work and family roles differently at each stage of their life (ChiChing, 1995). Support for this perspective is found in this study as some women identified different attitudes and means of coping depending on what was happening in their lives. For example, one woman mentioned that when she had been in a very demanding phase of her career development, she "used to take [work] home with me, and you could see everything was stressful. But now ... I've actually learned to keep things separate. When I spend time with [my son], I spend time with him, not thinking about work and that sort of thing". Another woman recalled a time when she had to be at work until midnight during a branch redecoration "to prove myself to the company. Sacrifices had to be made with my son, but it was only for three months. Now I don't need to prove myself anymore".

\section{Recommendations for future research}

In line with the ethos of qualitative research, this study focused on one organisation to take the context of the group's experiences into account. In particular, as with most studies carried out in the area of work-family conflict, the research was conducted in a large organisation. Future South African research may consider exploring the work and family issues experienced by employees in smaller organisations for the reason that the small business sector in this country is growing rapidly. Contextual consideration could have been taken further to explore the impact of broader social, political and economic issues, in particular, the effects that race and class have on the challenges faced by single working mothers in South Africa.

The fairly low Cronbach alphas attained for the two interference measures suggests that future research should employ more reliable scales to measure work-family conflict. In this regard, Duxbury et al. (1994) have recommended the scale developed by Gutek et al. (1991). This, as well as a larger sample, could provide more significant results with respect to the nature of the relationship between Central Life Interests and work-family conflict. Another possibility for future 
research is that of a comparative study between single and married working mothers with respect to the issues explored in this study. Comparing the experiences of single working mothers with those of married mothers would help to locate the results in terms of their significance.

\section{Conclusion}

The current study has shown that the experience of work-family conflict cannot be fully understood through a purely quantitative paradigm. The inclusion of a qualitative methodology and the exploration of participants' Central Life Interests provided a more in-depth understanding of the processes involved in balancing work and family demands. In particular, this research has provided tentative evidence for a relationship between Central Life Interests and work-family conflict.

In conclusion, this research has indicated that organisations need to be cognisant of the fact that many single working mothers view motherhood as their Central Life Interest. However, this does not imply that this group of women would neglect their work. On the contrary, results indicated that single working mothers view work as highly significant. This result, when viewed in combination with the finding that these single mothers experienced consistency between their personalities at home and at work, has powerful implications for the organisation. The characteristics and skills developed by single mothers as a result of their life experiences are carried through into the work environment and enable this group of women to be effective employees.

\section{REFERENCES}

Anderson, M. L. (1997). Thinking about women: Sociological perspectives on sex and gender. Boston: Allyn and Bacon.

Baba, V. V. (1989). Central life interests and job involvement: An exploratory study in the developing world. International Journal of Comparative Sociology, 30 (3-4), 181-194.

Bohen, H. \& Viveros-Long, A. (1981). Balancing jobs and family life. Philadelphia: Temple University Press.

Burns, A. \& Scott, C. (1994). Mother-headed families and why they have increased. Hillsdale, New Jersey: Lawrence Erlbaum Associates.

Census96. (1996). Community profile - Head of household. SuperSTAR for Windows programme.

Chi-Ching, Y. (1995). The effects of career salience and life-cycle variables on perceptions of work-family interfaces. Human Relations, 48 (3), 265-284.

Dubin, R. (1992). Central life interests: Creative individualism in a complex world. New Brunswick, New Jersey: Transaction Publishers.

Duxbury, L. E. \& Higgins, C. A. (1991). Gender differences in workfamily conflict. Journal of Applied Psychology, 76 (1), 60-74.

Duxbury, L., Higgins, C. \& Lee, C. (1994). Work-family conflict: A comparison by gender, family type, and perceived control. Journal of Family Issues, 15 (3), 449-466.

Eagle, B. W., Icenogle, M. L., Maes, J. D. \& Miles, E. W. (1998). The importance of understanding employee demographic profiles for understanding experiences of work-family interrole conflicts. The Journal of Social Psychology, 138 (6), 690-709.

Erasmus, B. (1997). Women power: Aspects of work life. Agenda, 35, 35-44.

Gecas, V. \& Seff, M. (1990). Social class and self-esteem: Psychological centrality, compensation and the relative effects of work and home. Social Psychology Quarterly, 53 (2), 165-173.

Goldberg, W. A., Greenberger, E., Hamill, S. \& O’Neil, R. (1992). Role demands in the lives of employed single mothers with preschoolers. Journal of Family Issues, 13 (3), 312-333.

Gringlas, M. \& Weinraub, M. (1995). The more things change...Single parenting revisited. Journal of Family Issues, $16(1), 29-52$.
Gutek, B. A., Searle, S. \& Klepa, L. (1991). Rational versus genderrole explanations for work-family conflict. Journal of Applied Psychology, 76 (4), 560-568.

Harpaz, I. \& Fu, X. (1997). Work centrality in Germany, Israel, Japan, and the United States. Cross-Cultural Research [Online]. Available: http://www.epnet.com/ehost/login.html

Hochschild, A. R. (1990). The second shift. New York: Avon.

Kossek, E. E. \& Ozeki, C. (1998). Work-family conflict, policies, and the job-life satisfaction relationship: A review and directions for organizational behaviourhuman resources research. Journal of Applied Psychology, 83 (2), 139-149.

Lambert, S. J. (1990). Processes linking work and family: A critical review and research agenda. Human Relations, 43 (3), 2390258.

Leiter, M. P. \& Durup, M. J. (1996). Work, home and inbetween: A longitudinal study of spillover. Journal of Applied Behavioural Science [On-line]. Available: http://www.epnet.com/ehost/login.html

Lewis, P., Saunders, M. \& Thornhill, A. (1997). Research methods for business students. London: Pitman.

Mannheim, B., Baruch, Y. \& Tal, J. (1997). Alternative models for antecedents and outcomes of work centrality and job satisfaction of high-tech personnel. Human Relations, 50 (12), 1537-1562.

Milkie, M. A. \& Peltola, P. (1999). Playing all the roles: Gender and the work-family balancing act. Journal of Marriage \& the Family [On-line]. Available: http://www.epnet.com/ehost/login.html

Millar, J. (1996). Mothers, workers, wives: Comparing policy approaches to supporting lone mothers. In E. B. Silva (Ed.), Good enough mothering? Feminist perspectives on lone motherhood (pp. 97-113). London: Routledge.

Netemeyer, R. G., Boles, J. S. \& McMurrian, R. (1996). Development and validation of work-family conflict and family-work conflict scales. Journal of Applied Psychology, 81 (4), 400-410

Nickols, S. Y. (1994). Work/family stresses. In P. C. McHenry \& S. J. Price (Eds.), Families and change: Coping with stressful events (pp. 66-87). Thousand Oaks, California: Sage Publications.

O'Driscoll, M. P., Ilgen, D. R. \& Hildreth, K. (1992). Time devoted to job and off-job activities, interrole conflict, and affective experiences. Journal of Applied Psychology, 77 (3), 27-279.

Parish, W. L. \& Hao, L. (1991). Family support networks, welfare, and work among young mothers. Journal of Marriage \& the Family [On-line]. Available: http://www.epnet.com/ehost/login.html

Pleck, J. H. (1985). Working wives, working husbands. Beverly Hills, California: Sage Publications.

Silva, E. B. (1996). Introduction. In E. B. Silva (Ed.), Good enough mothering? Feminist perspectives on lone motherhood (pp. 1-9). London: Routledge.

Simons, R. L. \& Conger, R. D. (1993). Stress, support, and antisocial behaviour trait as determinants of emotional wellbeing. Journal of Marriage \& the Family [On-line]. Available: http://www.epnet.com/ehost/login/html

Small, S. A. \& Riley, D. (1990). Toward a multidimensional assessment of work spillover into family life. Journal of Marriage \& the Family [On-line]. Available: http://www.epnet.com/ehost/login/html

Smart, C. (1999). The 'new' parenthood: Fathers and mothers after divorce. In E. B. Silva \& C. Smart (Eds.), The new family? (pp. 100-114). London: Sage Publications.

Smith, M. (1997). Psychology's undervaluation of single motherhood. Feminism and Psychology, 7 (4), 529-532.

Voydanoff, P. (1993). Work and family relationships. In T. H. Brubaker (Ed.), Family relations: Challenges for the future (pp. 98-111). Newbury Park, California: Sage Publications.

Wiley, M. G. (1991). Gender, work, and stress: The potential impact of role-identity salience and commitment. Sociological Quarterly [On-line]. Available: http://www.epnet.com/ehost/login/html 